\title{
Antibacterial activity of ethanolic extracts from Zingiber zerumbet rhizome against Salmonella spp.
}

\author{
IMBANG DWI RAHAYU ${ }^{1, \boldsymbol{}}$, WAHYU WIDODO ${ }^{2}$, INDAH PRIHARTINI ${ }^{2}$, ARIS WINAYA ${ }^{2}$ \\ ${ }^{1}$ Doctoral Program of Agricultural Science, Universitas Muhammadiyah Malang. Jl. Bendungan Sutami No.188, Malang City 65145, East Java, \\ Indonesia. Tel.: +62- 341-551149, ^email: dwirahayuimbang@gmail.com \\ ${ }^{2}$ Departemen of Agriculture Science, Graduate Program, Universitas Muhammadiyah Malang. J1. Bendungan Sutami No.188, Malang City 65145, East \\ Java, Indonesia
}

Manuscript received: 4 October 2019. Revision accepted: 26 October 2019.

\begin{abstract}
Rahayu ID, Widodo W, Prihartini I, Winaya A. 2019. Antibacterial activity of ethanolic extracts from Zingiber zerumbet rhizome against Salmonella spp. Biodiversitas 20: 3322-3327. The study aimed at investigating the antibacterial activity of ethanolic extracts of the Lempuyang Gajah (Zingiber zerumbet (L.) Smith) rhizome against Salmonella enteritidis ATCC 31194 and S. typhimurium ATCC 23564. An experimental method was employed for testing the antibacterial activity, with a completely randomized design (CRD) of factorial patterns. Factor I, ethanol concentrations which consisted of $45 \%$; $70 \%$ and $95 \%$, while factor II was the concentration of extracts, i.e $0 \% ; 2.5 \% ; 5 \% ; 7.5 \%$ and $10 \%$. The phytochemical screening results showed that the Z. zerumbet extracts with $45 \%$ and $70 \%$ ethanol, contained alkaloids, tannins, terpenoids, and saponins; however, the-95\%-ethanol did not result in any saponins, but flavonoids instead. Meanwhile, the chromatogram patterns of all extracts showed zerumbone is a dominant compound. Extraction of Z. zerumbet using $95 \%$ ethanol has higher antibacterial activity against S. enteritidis than S. typhimurium. The extract with $10 \%$ concentration gave the highest antibacterial activity than other concentrations. It can be concluded that the Z. zerumbet L. Smith extracts with $95 \%$ ethanol and $10 \%$ concentration has the best antibacterial activity against S. enteritidis. Whereas S. typhimurium is effectively inhibited by extracts with $45 \%$ ethanol and $7.5 \%$ extract concentration.
\end{abstract}

Keywords: Foodborne disease, phytobiotics, Salmonella enteritidis, Salmonella typhimurium, Zingiber zerumbet

\section{INTRODUCTION}

Salmonella enteritidis (S. enteritidis) and Salmonella typhimurium (S. typhimurium) are pathogen bacteria that commonly found in chicken and may cause contamination of chicken products (eggs or meat) either vertically or horizontally. It could lead to some foodborne-disease cases in various parts of the world including Indonesia, it may also become a carrier which causes several human diseases (Ariyanti and Supar 2008; Andino and Hanning 2015). Salmonella enteritidis infections have increased worldwide from the early 1970s and in 1990, this serovar replaced $S$. typhimurium as the leading cause of Salmonellosis in the world. In 1980 the S. enteritidis outbreak dramatically increased globally, posing a serious threat to the poultry industry and public health.

Meanwhile, the prevention of bacterial diseases using the addition of Antibiotic Growth Promoters (AGP) as a feed additive in livestock has been banned in Indonesia due to the negative impact. One of the most negative effects of the use of AGP is colonization-inhibition of some beneficial intestinal bacteria, such as Lactobacillus, Bifidobacteria (Vidanarachchi et al. 2005; Windisch et al. 2007), Boostereroides, and Enterococci (Panagiota et al. 2015). Thus, it may increase resistance against pathogenic bacteria, like Salmonella spp., including S. enteritidis and $S$. typhimurium which has proven could be found and isolated from broiler meat (Diaz-Sanchez et al. 2015; Thung et al. 2016).
On the other hand the use of AGP leaves antibiotic residues, such as sulfadiazine and oxytetracycline found in broiler meat (Diaz-Sanchez et al. 2015; Khatun et al. 2015), whereas, tetracycline, ampicillin, streptomycin, and an aminoglycoside are found in chicken kidney and liver (Kader et al. 2011; Sajid et al. 2016).

Phytobiotics generally consist of terpenoids (monoterpenoids, sesquiterpenes, and steroids), phenolics (tannins), glycosides, flavonoids alkaloids and glucosinolates, saponins, and zerumbone (Chang et al. 2012; Diaz-Sanchez et al. 2015). Rough extract of ethanol from the rhizome of $Z$. zerumbet can be used as an antibacterial agent to prevent from Gram-negative pathogenic bacterial diseases (Kader et al. 2011), including Salmonella spp.

Ethanol is a suitable solvent for active substances in $Z$. zerumbet in the form of alkaloids, flavonoids, tannins, and terpenoids (Pasril and Yuliasanti 2014), and is a versatile solvent that has the ability to extract with broad polarity, ranging from non-polar compounds to polar (Saifudin et al. 2011). Terpenoid compounds can inhibit the growth of microbes by interfering with the process of formation of membranes and/or cell walls, membranes or cell walls are not formed or formed imperfectly. Terpenoids can penetrate bacterial membranes and reach the inside of cells due to polysaccharide content and lipophilicity, so the cells are damaged (Hashemi and Davoodi 2010).

The use of various ethanol concentrations and $Z$. zerumbet extract concentration will result in the profile difference of the active compounds (phytochemicals) of 
extracts, which then will affect the antibacterial activity of the extracts. This study emphasizes the development of medicinal plants, namely Z. zerumbet $\mathrm{L}$. Smith as a natural antibacterial agent to Salmonella spp., so that it can be used as a substitute for AGP in poultry feed to ensure food safety.

\section{MATERIALS AND METHODS}

\section{Plant materials and preparation}

The $Z$. zerumbet L. Smith rhizome comes from UPT Materia Medica Batu, East Java, Indonesia, harvest age was 10 months. Complete determination shows that this plant includes Plantae kingdom, Spermatophyta division, Angiosperms subdivision, Monocotyledonae class, Zingiberaceae family, and Zingiber genus. Before the extraction process, the rhizomes are cleaned from attached soil, washed thoroughly, dried and thinly sliced, put into an oven (Hunan China XD-12) at $45^{\circ} \mathrm{C}$ for 5 days. Furthermore, it was grounded by a machine (Hunan China CFSJ-250B), $0.5 \mathrm{~kg}$ of powder was produced from the rhizome wet weight of $5.2 \mathrm{~kg}$. It takes 3 weeks for sample collection, from fresh rhizome to extract.

\section{Extraction of Zingiber zerumbet rhizome}

100 grams of rhizome powder that has been moistened with $45 \%$ ethanol solvent, put in a jar, flattened and added ethanol solvent until submerged as much as $1 \mathrm{~L}$, close the jar tightly for 24 hours after it is shaken on a digital shaker with a speed of $50 \mathrm{rpm}$. Next filter the liquid extract using a filter cloth and collected it in the Erlenmeyer tube. The results of the liquid extract were evaporated using a rotary evaporator for 1 hour, then the extract was evaporated over a water bath for 2 hours. The process produces $90 \mathrm{~mL}$ of liquid extract. In the extraction of 100 grams of powder using $70 \%$ ethanol, $65 \mathrm{~mL}$ of liquid extract was produced, while the extraction results with $95 \%$ ethanol from 150 grams of powder produced $49 \mathrm{~mL}$ of extract. The specifications of the equipment used for extraction are rotary evaporator, "Buchi" (R-215), made in Switzerland, digital shaker, "Wise Shake" (SHO-2D), from Korea, while oven and Waterbath, "Memmert", made in Germany, then alcoholmeter, "Gay Lussac", from Paris.

\section{Phytochemical screening}

The chemicals compound obtained from extracting could be identified as alkaloids, flavonoids, saponins, terpenoids, and tannins. Alkaloid was tested by using three types of reagents, namely Meyer, Dragendrouf and Bouchardat, all three are produced by Merck, Germany. Positive reaction was based on the formation of white, orange and brown deposits on each reagent (Ditjen POM 1986; Sudjadi 1986; Nugroho 2017). Flavonoids were tested by adding $0.5 \mathrm{~g}$ of $\mathrm{Mg}$ powder and three drops of concentrated $\mathrm{HCl}$ to the mixture of extract and hot aquadest. Red or pink color formation showed a positive reaction (Mojab et al. 2003). The saponins content was detected with shaking of the mixture of extract and hot aquadest strongly, permanent foaming formation for a minimum of 10 minutes as high as $1-10 \mathrm{~cm}$ mean positive reaction. The testing of steroids and triterpenoids based on the addition of Bouchardat reagents, the formation of a bluish-green color indicates steroids, meanwhile orange or brownish-orange color indicates triterpenoids. The tannin test was performed with the addition of $\mathrm{FeCl} 31 \%$. The existence of tannin is based on the formation of the color of blackish brown, blackish black, or dark green (Bintang 2010).

\section{Gas Chromatography-Mass Spectrometry (GC-MS)}

Gas Chromatography-Mass Spectrometry (GC-MS). GC-MS analysis of Z. zerumbet rhizome ethanolic extract was carried out using Perkin Elmer GC-MS (Perkin Elmer Clarus 680 GC-Clarus SQ 8T MS) which has an Elite-5 MS capillary column $30 \mathrm{~m} \times 0.25 \mathrm{~mm} \times 25 \mu \mathrm{m}(5 \%$ diphenyl, 95\% dimethylpolysiloxane, GC-MS was detected using an electron ionization system with $70 \mathrm{eV}$ ionization energy. Gas carrier in the form of helium ultrapure was used with a constant flow rate of $1 \mathrm{~mL} / \mathrm{min}$. The ion source, mass transfer path, and injector temperature are respectively set at $230^{\circ} \mathrm{C}, 250^{\circ} \mathrm{C}$, and $290^{\circ} \mathrm{C}$. The oven temperature is set between 50 to $150^{\circ} \mathrm{C}$ at $3^{\circ} \mathrm{C} / \mathrm{min}$ and in isothermal conditions for 10 minutes and subsequently raised to $250^{\circ} \mathrm{C}$ at $10^{\circ} \mathrm{C} /$ minute. Diluted samples (1/100, $\mathrm{v} / \mathrm{v}$ in ethanol) from $1 \mathrm{wL}$ were manually injected in split mode 120. Mass spectral scanning was in the range of 45$450 \mathrm{~m} / \mathrm{z}$ with a solvent delay of 2 minutes. The extract components were identified based on comparison of the relative GC retention time and mass spectrum with components from NIST MS Search Library Software version 2.0. Cat $10^{\circ} \mathrm{C} / \mathrm{min}$ (Valle et al. 2016).

\section{Microorganism}

The isolate used in this research was Salmonella spp., consisting of S. enteritidis serovar ATCC 31194 and S typhimurium serovar ATCC 23564. These isolates were obtained from the laboratory of microbiology, Universitas of Brawijaya, Malang, East Java.

\section{Screening of the extracts for the antibacterial activity}

To investigate the antibacterial activity of the extracts against $S$. enteritidis, an experimental method with a completely randomized design (RAL) of factorial patterns was utilized. Factor I was concentration of ethanol solvent: $45 \%, 70 \%$ and $95 \%$, factor II was $Z$. zerumbet extract concentration: $0 \% ; 2.5 \% ; 5 \%, 7.5 \%$, and $10 \%$, replicated 10 times. The measured variable is the Minimal Inhibitory Concentration (MIC) employing microdilution and diffusion methods, which are sequentially used to obtain data on the effect of treatment on cell counts and inhibition zones of Salmonella spp. (Sutardi et al. 2015).

\section{Statistical analysis}

The phytochemical screening data were analyzed descriptively quantitatively, while the number and inhibitory zones of Salmonella spp.. were analyzed using ANOVA, differences among the treatment were tested by Duncan's Multiple Range Test (DMRT) method. The analysis was carried out through the SPSS program (Statistical Packages for Social Science). 
Table 1. Chemical compounds of phytochemical screen of Zingiber zerumbet ethanolic extracts

\begin{tabular}{|c|c|c|c|c|c|c|}
\hline \multirow[b]{2}{*}{$\begin{array}{l}\text { Zingiber } \\
\text { zerumbet } \\
\text { extracts conc. } \\
(\%)\end{array}$} & \multicolumn{6}{|c|}{ Phytochemicals } \\
\hline & $\begin{array}{l}\frac{n}{0} \\
\frac{0}{0} \\
\frac{\pi}{=}\end{array}$ & 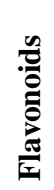 & 咅 & & : & $\frac{0}{0}$ \\
\hline 45 & + & - & + & + & + & - \\
\hline 70 & + & - & + & + & + & - \\
\hline 95 & + & + & - & + & + & - \\
\hline
\end{tabular}

Table 2. The influence of ethanol concentration on the cell number and inhibition zone of Salmonella spp.

\begin{tabular}{|c|c|c|c|c|}
\hline \multirow{2}{*}{$\begin{array}{l}\text { Zingiber } \\
\text { zerumbet } \\
\text { extracts } \\
\text { conc. }(\%)\end{array}$} & \multicolumn{2}{|c|}{$\begin{array}{c}\text { Cell number of } \\
\text { Salmonella spp }\left(\times 10^{8}\right. \\
\text { CFU/mL) }\end{array}$} & \multicolumn{2}{|c|}{$\begin{array}{l}\text { Inhibition zone } \\
\quad(\mathbf{m m})\end{array}$} \\
\hline & 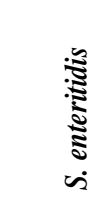 & 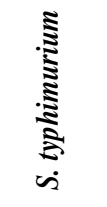 & 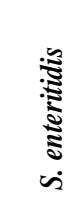 & 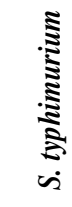 \\
\hline 45 & $2.31^{\mathrm{c}}$ & $3.97^{b}$ & $2.41^{\mathrm{a}}$ & $1.90^{\mathrm{c}}$ \\
\hline 70 & $2.41^{\mathrm{b}}$ & $4.52^{\mathrm{c}}$ & $3.40^{\mathrm{c}}$ & $1.79^{b}$ \\
\hline 95 & $1.67^{\mathrm{a}}$ & $2.34^{\mathrm{a}}$ & $2.65^{\mathrm{b}}$ & $0.00^{\mathrm{a}}$ \\
\hline
\end{tabular}

Note: The number followed by different letters in the same column shows the difference in the 5\% Duncan Test

\section{RESULTS AND DISCUSSION}

\section{Phytochemical Screening}

The results of phytochemical screening of the ethanolic extracts of $Z$. zerumbet are shown in Table 1. The phytochemical screening based on 3 types of reagents consist of Meyer, Dragendrouf and Bouchardat showed that $Z$. zerumbet extracts depict various beneficial chemical compounds, namely saponins, tannins, alkaloids, flavonoids, and triterpenoids. This findings showed that $Z$ zerumbet has properties as phytobiotic, supported by previous theories, in which the positive effects of phytobiotics are mainly related to the plant constituents including terpenoids (monoterpenoids, sesquiterpenes, and steroids), phenolic (tannins), glycosides, alkaloids (as alcohols, aldehydes, ketones, esters, ether, and lactones), flavonoids and glucosinolate (Chang et al. 2012; DiazSanchez et al. 2015). Extractions with the polar solvents water, ethanol, or methanol have identified phenolics, flavonoids, and sesquiterpenoids in $Z$. zerumbet (Ganapathy and Nair 2017).

Based on Table 1, the Z. zerumbet extract with ethanol concentrations of $45 \%$ and $70 \%$ contain saponins, tannins, and triterpenoids, while $95 \%$ of ethanol concentrations contain tannins, triterpenoids, and flavonoids. The results of this study are consistent with the statement by Pasril and Yuliasanti (2014) that ethanol is a suitable solvent for extracting active compounds from $Z$. zerumbet. The mechanism of active compounds as antibacterial is by disrupting the biochemical processes of bacterial cells, including inhibition of cell wall synthesis, cell membrane function, and protein synthesis. Alkaloids, terpenoids, and tannins have been successfully extracted from rhizome $Z$. zerumbet with ethanol at various concentrations $(45 \%, 70 \%$ and 95\%), this has an important meaning that the three compounds effective as antibacterials to suppress the growth of Gram-negative bacteria, because bacterial cell walls consist of polar lipopolysaccharides (LPS) (Huang et al. 2019).

The alkaloids that have been successfully extracted from the $Z$. zerumbet rhizome were suspected in the form of salt, as stated by Hanani (2014) and Harborne (2006), alkaloids are bound to organic acids found in plants, such as succinic acid, maleic, meconic, kinic, and is soluble in ethanol or water solvents. Ethanolic extract from $Z$. zerumbet does not contain steroids, so saponins that have been successfully extracted are likely to be triterpenes saponins, according to the statement by Leland (2006) and (Hanani 2014) that saponins are grouped into steroid and triterpenes, which are water-soluble, not soluble in ether. Reported by Sirait (2007) that triterpenes saponins are usually acidic because it contains one or two carbonyl groups in the aglycone, and it's an alcohol, aldehyde or carboxylic acid.

Flavonoids in $Z$. zerumbet successfully extracted with 95\% ethanol solvent, it can be assumed that the flavonoids contained in the extract are in the form of glycosides, perhaps as flavonoids-O-glycosides or flavonoids-Cglycosides, bound to sugar. In line with the statements of Hanani (2014) and Harborne (2006), flavonoids are polyphenol compounds, present in two forms, namely aglycones, are less polar (isoflavones, flavanones, flavonoids and methylated flavones), soluble only in low polarity compounds, such as chloroform and ether, but can also be in the form of polar glycosides, so that they dissolve easily in polar solvents, such as ethanol. Several types of flavonoids contained in $Z$. zerumbet rhizome extract, including quercetin, kaempferol, catechin, and myricetin, whose levels are increasing according to increasing plant age (Ghasemzadeh et al. 2016).

\section{Analysis of chemical compound components of the ethanolic extracts with GCMS}

The qualitative data from the GCMS method in $45 \%$, $70 \%$ and $95 \%$ ethanolic extracts of $Z$. zerumbet are displayed in Figure1, Figure 2, and Figure 3.

The most dominant compound contained in the extracts of $Z$. zerumbet with various concentrations of ethanol is zerumbone, in the $45 \%, 70 \%$, and $95 \%$ ethanol, the zerumbone contents are as much as $91.011 \%, 75.422 \%$, and $43.143 \%$ respectively (Figures 1, 2, 3). Moreover, other compounds, namely alpha-humulene, linalool, and humaladienone are also discovered in $95 \%$ of ethanolic extract, which becomes the most complete extract content of all active compounds. This result is in accordance with the results of previous studies, that zerumbone is the most common compound found in $Z$. zerumbet crude ethanolic extract (Yob et al. 2011), and belongs to the 
sesquiterpenoid group, generally a component of essential oils (Dai et al. 2013 and Golam et al. 2010; Hanani 2014), with a level of $90.62 \%$ in the essential oil fraction obtained by steam and water distillation (Mulyani 2010). SharifiRad et al. (2017) also reported that $Z$. zerumbet essential oil obtained by hydrodistillation from rhizomes containing zerumbone (69.9\%), $\alpha$ humulene (12.9\%), humulene epoxide II (2.5\%), caryophyllene oxide (1.1\%) and camphene $(1.9 \%)$. Zerumbone has antimicrobial activity as a powerful antibacterial and anti-fungal (Bhuiyan et al. 2009). In addition to zerumbone, $Z$. zerumbet also contain bioactive compounds, namely humulene, and monoterpenes (Yob et al. 2011). Z. zerumbet contains various terpenoid types, including pinene, camphor, linalool, zerumbone, limonene, camphene, caryophyllene, 3-carene, 4-terpineol and eucalyptol (Bhuiyan et al. 2009). $Z$. zerumbet is also known to contain sesquiterpenes, zederon phenolics, saponins and terpenoids (Kader et al. 2011; Kader et al. 2010; Hashemi et al. 2008 and Yob et al. 2011).

\section{In vitro antibacterial activity}

The result of ANOVA shows that the ethanol concentration, the extract concentration and the interaction between both significantly influence the number of Salmonella spp. The DMRT test results of the effect of ethanol concentration on the cell number and inhibition zone of Salmonella spp. are shown in Table 2, while effect of $Z$. zerumbet extract concentration is shown in Table 3 .

Based on Table 2 and Table 3, the study generally shows that ethanolic extract from $Z$. zerumbet has better antibacterial activity against $S$. enteritidis than $S$. typhimurium. The cell number of $S$. enteritidis is fewer and the inhibition zone of the extracts is wider than $S$. typhimurium. Salmonella spp. is a Gram-negative bacteria, with their cell walls containing LPS components; thus its sensitivity is low to Z zerumbet extracts. It is proven that the cell number of Salmonella spp. is still high, between $1.67 \times 10^{8} \mathrm{CFU} / \mathrm{mL}$ to $4.52 \times 10^{8} \mathrm{CFU} / \mathrm{mL}$ and low inhibition zone, which is between $0.00 \mathrm{~mm}$ to $3.68 \mathrm{~mm}$. It was reported that in general Gram-positive bacteria are more sensitive to antimicrobial compounds than Gramnegative bacteria, this is related to differences in the composition of cell walls, the Gram-negative structure consists of lipopolysaccharides which make the cell walls impermeable to lipophilic solutes, unlike bacteria Grampositive which does not have this outer membrane (Kumar et al. 2013; Liu et al. 2013; Ghasemzadeh et al. 2016). Based on these reasons we suspect that $S$. enteritidis is more sensitive to ethanolic extracts from $Z$. zerumbet than $S$. typhimurium because the outer membrane is more hydrophilic, so the extract easily penetrates it. This is related to the content of several active compounds, such as flavonoids, alkaloids, tannins, and terpenoids (zerumbone) (Table 1, Figure 3) in Z. zerumbet ethanolic extracts. The action mechanisms of such active substances are in forms of inhibiting the cell wall synthesis, the cell membrane function and the protein synthesis (Bhuiyan et al. 2009; Pasril and Yuliasanti 2014).

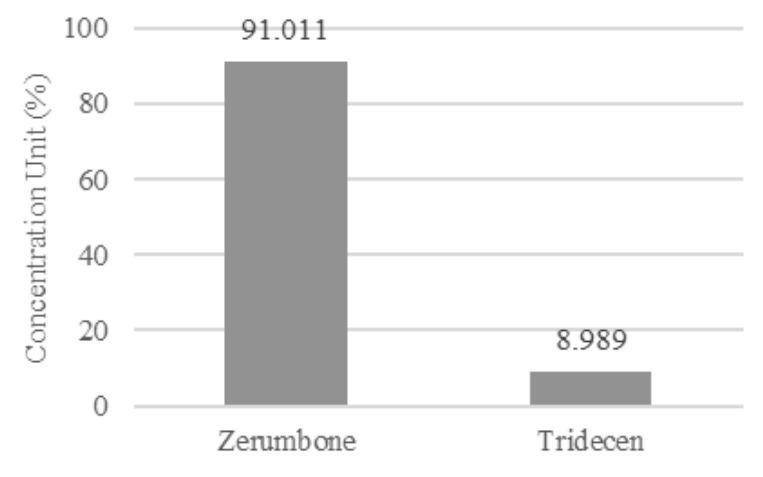

Figure 1. The compounds result of GCMS method in $45 \%$ ethanolic extract of Zingiber zerumbet

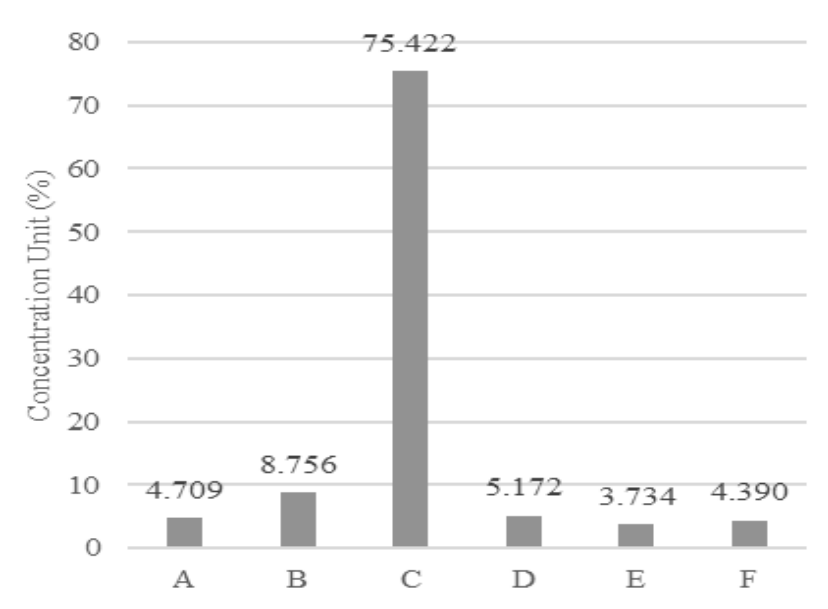

Figure 2. The compounds result in GCMS method in 70\% ethanolic extract of Zingiber zerumbet. A: Tridecatretane, B: Humuladienone, C: Zerumbone, D: Patchulane, E: Pentadecanoic acid, F: octadecadienoic acid

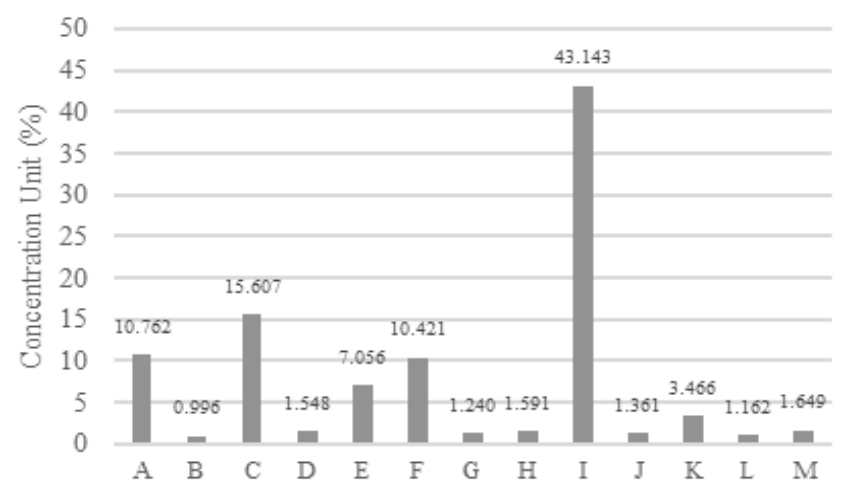

Figure 3. The compounds result in GCMS method in 95\% ethanolic extract of Zingiber zerumbet. A: Linalool, B: Bicyclo [2.2.1] heptane-2-one, C: Alpha-Humulene, D: Patchulane, E: 7Pentadecen-5-yne, F: Humuladienone, G: Curdione, H: Cis-1,7Octadiene-3-yl acetate, I: Zerumbone, J: 1,5,9-Decatriene, K: Ledane, L: Pentadecanoic acid, M: Bicyclol (3,1,1 Heptane. 2,6,6trimethyl 
Table 3. The influence of Zingiber zerumbet extract concentration on the cell number and inhibition zone of Salmonella spp.

\begin{tabular}{ccccc}
\hline Zingiber zerumbet & \multicolumn{2}{c}{ Cell number of Salmonella spp. $(\times \mathbf{1 0} \mathbf{~ C F U ~} / \mathbf{m L})$} & \multicolumn{2}{c}{ Inhibition zone (mm) } \\
\cline { 2 - 5 } extracts conc. $(\%)$ & S. enteritidis & S. typhimurium & S. enteritidis & S. typhimurium \\
\hline 2.5 & $2.30^{\mathrm{c}}$ & $3.70 \mathrm{~b}$ & $1.84^{\mathrm{a}}$ & $0.52^{\mathrm{a}}$ \\
5.0 & $2.35^{\mathrm{cd}}$ & $3.56^{\mathrm{ab}}$ & $2.38^{\mathrm{b}}$ & $1.00^{\mathrm{b}}$ \\
7.5 & $2.19^{\mathrm{b}}$ & $3.72^{\mathrm{bc}}$ & $3.37^{\mathrm{c}}$ & $1.88^{\mathrm{d}}$ \\
10 & $1.68^{\mathrm{a}}$ & $3.46^{\mathrm{a}}$ & $3.68^{\mathrm{d}}$ & $1.52^{\mathrm{c}}$ \\
\hline
\end{tabular}

Note: The number followed by different letters in the same column shows the difference in the 5\% Duncan Test. Alphabet cd means there was no difference in the number of $S$. enteritidis cells in the use of extract with concentrations of $2.5 \%$ and $5 \%$. Alphabet ab means there was no difference in the number of S. typhimurium cells in the use of extract with concentrations of $2.5 \%$ and $5 \%$. Alphabet bc means there was no difference in the number of S. typhimurium cells in the use of extract with concentrations of $2.5 \%$ and $7.5 \%$

Flavonoids are found only in $95 \%$ of ethanolic extracts of $Z$. zerumbet, they can inhibit phosphodiesterase, aldol reductase, monoamine oxidase, protein kinase, DNA polymerase as well as lipoxygenase (Linarti et al. 2011). The inhibitory action of tannins on microbes occurs in cell membranes, through cell aggregation and disruption of membranes and cell function, in general tannins cause protein deposition, but tannin's anti-microbial activity is specific, according to the chemical composition and structure of tannins. Condensed tannins isolated from several plants have been shown to have strong activity against Gram-negative bacteria, including Salmonella, Shigella, Staphylococcus, Pseudomonas and Helicobacter pylori (Liu et al. 2013; Wang et al. 2013). Tannins are known to have anti-inflammatory, astringent, and antiseptic activities, they inhibit the enzyme systems of microorganisms, tannic acid inhibits phosphatidylcholine liposomes which damage microorganism membranes, is also able to bind iron that is needed by microorganisms, resulting in malfunctioning of aerobic microorganisms (Linarti et al. 2011).

The alkaloid compound has an inhibitory mechanism by disrupting the peptidoglycan component of the bacterial cell, so that the cell wall layer is not formed completely or imperfectly and causes the cell's death (Juliantina et al. 2008; Retnowati et al. 2011). In alkaloids there are alkaline groups that contain nitrogen, alkaloid compounds will react with amino acids that make up the bacterial cell wall and bacterial DNA. Alkaloids are known as DNA intercalators and inhibitors of DNA synthesis, by inhibiting the topoisomerase enzyme (Gunawan 2008; Hashemi and Davoodi 2010). The hydrophilic nature of the alkaloids also makes it easier for the alkaloids to penetrate the additional layer (outer membrane) of the Gram-negative bacterial cell wall consisting of LPS. The hydrophilic side of the Gram-negative bacterial cell wall is a carboxyl group, an amino acid, and a hydroxyl group.

Saponins contained in ethanolic extract (45\% and $70 \%)$ (Table 1) have antibacterial activity, as reported by Netala et al. (2015) that it can damage the hydrophobic bonds of cell membrane components, such as proteins and phospholipids, as well as the dissolution of hydrophilic components. Saponins also destroy the bivalent cationic bonds, including $\mathrm{Ca}^{2+}$ and $\mathrm{Mg}^{2+}$ with LPS in Gramnegative bacteria. Added by Arabski et al. (2009) and Ye et al. (2012) that saponins are also capable of interacting with cell membrane components, such as lipid A, which can cause increased permeability of the cell walls of Gramnegative bacteria. One type of saponins, namely camelliagenin, can interact with bacterial biofilm components, i.e., Mannitol Dehydrogenase (MDH) or extracellular DNA (eDNA) of Escherichia coli and Staphylococcus aureus. As stated by Aiello and Susan (2012), saponins may work as an antimicrobial; this compound can crush the cytoplasmic membrane and kill the cell.

Zerumbon has antimicrobial activity, as a strong antibacterial and anti-fungal (Bhuiyan et al. 2009; Kumar et al. 2013), because zerumbone has ketone groups on C-8 atoms so it is polar, which can be extracted using polar and semi-polar solvents (Kapitan et al. 2017). Polarity of antimicrobial compounds is an important chemical property, because compounds can dissolve in the water phase where microbes generally grow in the water phase.

It can be concluded that extraction of $Z$. zerumbet using 95\% ethanol solvent has higher antibacterial activity against $S$. enteritidis than $S$. typhimurium. The extract with $10 \%$ concentration gave the highest antibacterial activity than other concentrations. At this concentration, the extract provides antibacterial activity against $S$. enteritidis which is higher than $S$. typhimurium. Whereas $S$. typhimurium is effectively inhibited by extracts with $45 \%$ ethanol and $7.5 \%$ extract concentration.

\section{ACKNOWLEDGEMENTS}

Thank you to the Directorate of Research and Community Service, the Indonesian Ministry of Research, Technology and Higher Education and Chancellor of the University of Muhammadiyah, Malang, Indonesia who have funded and provided the facilities and infrastructure for Doctoral Dissertation Research (PDD).

\section{REFERENCES}

Ariyanti T, Supar. 2008. Antigenisitas dan imunogenisitas Salmonella enteritidis: Implikasi dalam diagnosis dan pengembangan vaksin isolat lokal untuk unggas. Wartazoa 18 (4): 187-197. [Indonesian]

Andino A, Hanning I. 2015. Salmonella enterica: Survival, colonization, and virulence differences among serovars. Sci World J 2015: 520179. DOI: $10.1155 / 2015 / 520179$. 
Arabski M, Wasik S, Dworecki K, Kaca W. 2009. Laser interferometric and cultivation methods for measurement of colistin/ampicillin and saponin interactions with smooth and rough of Proteus mirabilis lipopolysaccharides and cells. J Microbiol Methods 77: 178-183.

Aiello, Susan E. 2012. The Merck itinerary manual. Merck Sharp \& Dohme Corp, USA.

Bintang M. 2010. Biokimia Teknik Penelitian. Erlangga Medical Series, Jakarta. [Indonesian]

Bhuiyan MNI, Chowdhury JU, Begum J. 2009. Chemical investigation of the leaf and rhizome essential oils of Zingiber zerumbet (L.) Smith from Bangladesh. Bangladesh J Pharmacol 4: 9-12. DOI: 10.3329/bjp.v4i1.845

Chang CJ, Tzeng T, Liou S, Chang Y, Liu I. 2012. Acute and 28-day subchronic oral toxicity of an ethanolic extract of Zingiber zerumbet (L.) Smith in rodents. Evid-Based Compl Altern Med 2012: 608284 DOI: $10.1155 / 2012 / 608284$

Diaz-Sanchez S, D’Souza D, Biswas D, Hanning I. 2015. Botanical alternatives to antibiotics for use in organic poultry production. Pollut Sci J 94: 1419-1430

Dai DN, Tran DT, Le TMC, Isiaka AU. 2013. Chemical constituents of the root essential oils of Zingiber rubens Roxb., and Zingiber zerumbet (L.) Smith. Am J Plant Sci 4: 7-10. DOI: 10.4236/ajps.2013.41002

Ditjen POM. 1986. Sediaan Galenik. Departemen Kesehatan Republik Indonesia, Jakarta. [Indonesian]

Gunawan. 2008. Antibakteri pada herba meniran (Phyllanthus niruri Linn). Jurnal Kimia 2 (22): 31-39. [Indonesian]

Golam M, Rowshanul M, Mohammad A, Mukhlesur M. 2010. Zederone from the rhizomes of Zingiber zerumbet and its anti-staphylococcal activity. Boletín Latinoamericano y del Caribe de PlantasMedicinales y Aromáticas 9 (1): 63-68.

Ghasemzadeh A, Jaafar HZE, Ashkani S, Rahmat A, Juraimi AS, Puteh A, Mohamed MMT. 2016. Variation in secondary metabolite production as well as antioxidant and antibacterial activities of Zingiber zerumbet (L.) at different stages of growth. BMC Complement Altern Med 16 104. DOI: 10.1186/s12906-016-1072-6

Ganapathy G, Nair AR. 2017. Curcuminoids in Zingiber zerumbet rhizomes: Bioguided fractionation and chromatographic identification of antimicrobial and antioxidant metabolites. J Herbs Species Med Plants 23 (2): 169-181. DOI: 10.1080/10496475.2017.1283555

Hanani E. 2014. Analisis Fitokima. Penerbit Buku Kedokteran EGC, Jakarta. [Indonesian]

Hashemi SR, Zulkifli I, Bejo MH, Farida A, Somchit MN.2008. Acute toxicity study and phytochemical screening of selected herbal aqueous extract in broiler chickens. Int J Pharmacol 4 (5): 352-360. DOI: 10.3923/ijp.2008.352.360

Hashemi SR, Davoodi H. 2010. Phytogenics as new class of feed additive in poultry industry. JAVA 9 (17): 2295-2304

Harborne JB. 2006. Metode Fitokimia Penentun Cara Modern Menganalisis Tumbuhan. Terbitan Kedua. Cetakan Keempat. Penerbit ITB, Bandung. [Indonesian]

Huang Q, Liu X, Zhao G, Hu T, Wang Y. 2018. Potential and challenges of tannins as an alternative to in-feed antibiotics for farm animal production. Anim Nutr 4 (2): 137-150. DOI: 10.1016/j.aninu.2017.09.004

Juliantina FR, Citra DAM, Nirwani B. 2008. Manfaat sirih merah (Piper crocatum) sebagai agen anti bakteri terhadap Gram Positif dan Gram Negatif. Jurnal Kedokteran dan Kesehatan Indonesia 15: 1-10. [Indonesian]

Khatun R, Howlader MA, Islam MN, Alam MK, Mahmud MS, Rahman MH. 2015. Exploration of the causes of infectious illness and detection of antibiotic residues in warehouse poultry. Am J Food Technol 1 (2): 57-62.

Kader G, Nikkon F, Rashid MA, Yeasmin T. 2011. Antimicrobial activities of the rhizome extract of Zingiber zerumbet SM. Asian Pac J Trop Biomed 1 (5): 409-412.

Kader MG, Habib MR, Nikkon F, Yeasmin T, Rashid MA, Rahman MM. 2010. Zederone from the rhizomes of Zingiber zerumbet and its antistaphylococcal activity. Boletín Latinoamericano y del Caribe de PlantasMedicinales y Aromáticas 9 (1). 63-68.

Kapitan OB, Ambarsari L, Falah S. 2018. In vitro antibakteri ekstrak etanol puni (Zingiber zerumbet) asal Pulau Timor. Savana Cendana 2 (2): 29-32. DOI: DOI: 10.32938/sc.v2i02.82. [Indonesian]

Kumar SC, Srinivas P, Negi PS, Bettadaiah BK. 2013. Antibacterial and antimutagenic activities of novel zerumbone analogues. Food Chem 141 (2): 1097-1103. DOI: 10.1016/j.foodchem.2013.04.021
Leland JC. 2006. Natural products from plants. 2nd eds. CRC Press, Boca Raton, FL.

Linarti R, Muslihah S, Nuri. 2011. Uji antiinflamasi ekstrak metanol daun sirih merah (Piper crocatum Ruiz \& Pav) pada tikus putih. Trad Med J 16 (1): 34-42. [Indonesian]

Liu XL, Hao YQ, Jin L, Xu ZJ, McAllister TA, Wang Y. 2013. AntiEscherichia coli O157: H7 properties of purple prairie clover and sainfoin condensed tannins. Molecules 18: 2183-2199.

Mulyani S. 2010. Komponen dan anti-bakteri dari fraksi kristal minyak Zingiber zerumbet. Majalah Farmasi Indonesia 21 (3): 178-184. [Indonesian]

Mojab F, Kamalinejad M, Ghaderi N, Vahidipour HR. 2003. Phytochemical screening of some species of Irian Plants. Iranian J Pharmaceut Res 2 (2): 77-82

Netala VR, Ghosh SB, Bobbu P, Aniyha D, Tartte V. 2015. Triterpenoid saponin: A review on biosynthesis, applications, and mechanism of their action. Int J Pharm Pharm Sci 7 (1): 24-28.

Nugroho A. 2017. Teknologi Bahan Alam. Lambung Mangkurat University Press, Banjarmasin. [Indonesian]

Panagiota G, Vangelis E, Petros B, Chrissanthy P. 2015. Vancomycinresistance phenotypes, vancomycin-resistance genes, and resistance to antibiotics of Enterococci isolated from food of animal origin. Foodborne Pathog Dis 12 (3): 214-220. DOI: 10.1089/fpd.2014.1832

Pasril Y, Yuliasanti A. 2014. Daya antibakteri ekstrak daun sirih merah (Piper crocatum) terhadap bakteri Enterococcus faecalis sebagai bahan medikamen saluran akar dengan metode dilusi. Insisiva Dental J 3 (1): 88-95. [Indonesian]

Retnowati Y, Bialangi N, Posangi NW. 2011. Pertumbuhan bakteri Staphylococcus aureus pada media yang diekspos dengan infus daun sambiloto (Andrographis paniculata). Saintek 6 (2): -. [Indonesian]

Sajid A, Kashif N, Kifayat N, Ahmad S. 2016. Detection of antibiotic residues in poultry meat. J Pharm Sci 29 (5): 1691-1694.

Sharifi-Rad M, Varoni EM, Salehi B, Sharifi-Rad J, Matthews KR, Ayatollahi SA, Rigano D. 2017. Plants of the genus Zingiber as a source of bioactive phytochemicals: From tradition to pharmacy. Molecules 22 (12): 1-23.

Sirait M. 2007. Penuntun Fitokimia dalam Farmasi. Penerbit ITB, Bandung. [Indonesian]

Sutardi LN, Wientarsih I, Handharyani E, Setiyono A. 2015. Indonesian wild ginger ( Zingiber sp ) extract Antibacterial activity against Mycoplasma gallisepticum. IOSR J Pharm 5 (10): 59-64.

Sudjadi. 1986. Metode Pemisahan. UGM Press, Yogyakarta. [Indonesian]

Saifudin A, Rahayu V, Teruna HY. 2011. Standarisasi Bahan Obat Bahan Alam. Graha Ilmu, Yogyakarta. [Indonesian]

Thung TY, Mahyudin NA, Basri DF, Wan Mohamed Radzi CWJ, Nakaguchi Y, Nishibuchi M, Radu S. 2016. Prevalence and antibiotic resistance of Salmonella enteritidis and Salmonella typhimurium in raw chicken meat at retail markets in Malaysia. Poult Sci 95 (8): 1888-1893

Vidanarachchi JK, Mikkelsen LL, Sims IM, Iji PA, and Choct H. Phytobiotics: alternatives to antibiotic growth promoters in monogastric animal feeds. Recent Adv Anim Nutri Aust 15: 131-144.

Valle DL, Puzon JJM, Cabrera EC, Rivera WL. 2016. Thin Layer Chromatography-Bioautography and Gas Chromatography-Mass Spectrometry of antimicrobial leaf extracts from Philippine Piper betle L. against Multidrug-Resistant Bacteria. Hindawi Publishing Corporation. Evid-Based Compl Altern Med 2016: 4976791. DOI: $10.1155 / 2016 / 4976791$

Wang Y, Jin L, Ominski KH, He M, Xu Z, Krause DO. 2013. Screening of condensed tannins from Canadian prairie forages for antiEscherichia coli O157: $\mathrm{H} 7$ with an emphasis on purple prairie clover (Dalea purpurea vent). J Food Prot 76 (4): 560-567

Windisch WM, Schedle K, Plitzner C, Kroismayr A. 2007. Use of herbal extracts as feed additives for swine and poultry. J Anim Sci 86: 140148.

Ye Y, Yang Q, Fang F, Li Y. 2015. The camelliagenin from defatted seeds of Camellia ollifera as antibiotic substitute to treat chicken against infection of Escherichia coli and Staphylococcus aureus. BMC Vet Res 11: 214.

Yob NJ, Mohd S, Jofrry, Zakaria ZA. 2011. Zingiber zerumbet (L.) Smith: A Review of Its ethnomedicinal, chemical, and pharmacological uses. Hindawi Publishing Corporation. Evid-based Compl Altern Med 2011: 543216. DOI: 10.1155/2011/543216. 